EUROPA REGIONUM TOM XXVIII ROK 2016

DOI: $10.18276 /$ er.2016.28-10

AGATA KIELESIŃSKA

Uniwersytet Zielonogórski

\title{
Aspekt agroturystyki w rozwoju lokalnym
}

\section{Wprowadzenie}

ukcesywnie wzrasta zainteresowanie turystyką alternatywną, która obejmuje


krajoznawczych, uprawianej $\mathrm{w}$ małych grupach lub indywidualnie, zwykle związanej z określonymi specyficznymi cechami lub środowiskiem (np. turystyka wiejska, agroturystyka, ekoturystyka).

Turystyka wiejska nie jest zjawiskiem nowym ${ }^{1}$, związana jest z przestrzenią rekreacyjną, ale także z szerokim spektrum działalności ludzkiej na wsi, jej historią, kulturą, religią oraz ogólnym pojęciem etnografii. Stanowi jednocześnie dodatkowe źródło dochodu dla rolników prowadzących działalność związaną z otoczeniem turystyki oraz przyczynia się do dywersyfikacji lokalnej gospodarki i rynku pracy oraz rozwoju lokalnej infrastruktury.

Turystyka wiejska, utożsamiana często $\mathrm{z}$ agroturystyką ${ }^{2}$, jest szerszym pojęciem i obejmuje całokształt gospodarki turystycznej związanej z rozbudową całej infrastruktury technicznej, ekonomicznej i społecznej, na obszarach wiejskich w zakresie wypoczynku organizowanego, a związanego z walorami turystyczno-rekreacyjnymi danego regionu, w tym np.: czynnego uprawiania sportów letnich, zimowych, zbieranie runa leśnego, łowienie ryby, fotografowanie

${ }^{1}$ Wyjazdy w tereny wiejskie „na letnisko” były popularne już w XIX w. Dzisiaj tylko wracamy do tej starej, dobrej tradycji, ale w nowej, zorganizowanej formie.

${ }^{2}$ Różne formy usługi działalności turystycznych, nie związanych bezpośrednio z działalnością gospodarstwa rolnego, niesłusznie przyjęło się nazy wać agrotury styka - transponując nazewnictwo używane w wielu krajach, zwłaszcza w Ameryce Północnej dla takiej formy turystyki określanej jako agricultural tourism, agritourism czy vacation farm tourism. 
krajobrazów, zwierząt i ptaków, zwiedzania okolicy, zabytków kulturalnych i historycznych, uczestniczenie w regionalnych wydarzeniach folklorystycznych. Staje się ona jednym z narzędzi restrukturyzacji i modernizacji regionów, poprzez przebudowę i dywersyfikację struktury gospodarczej wsi, szczególnie o słabym rolnictwie.

Natomiast agroturystyka, jest częścią składową turystyki wiejskiej, ale obejmuje pobyt turystów $\mathrm{w}$ gospodarstwie i na terenie wsi u rodziny rolniczej. Stanowi ,rodzaj turystyki alternatywnej na terenach wiejskich organizowany przez rodziny rolnicze $\mathrm{z}$ wykorzystaniem zasobów gospodarstwa rolnego oraz zasobów przyrodniczych, kulturowych i infrastrukturalnych wsi i regionu" i jest formą wypoczynku $\mathrm{z}$ zamieszkaniem $\mathrm{w}$ funkcjonującym gospodarstwie rolnym. Agroturystyką jest także zakwaterowanie ( $\mathrm{z}$ własną obsługą) na terenach należących do gospodarstwa, np. w domkach, w pojazdach kempingowych i na polach namiotowych gospodarstwa.

Cechy wspólne agroturystyki i turystyki wiejskiej, to: lokalizacja na obszarach wiejskich, z reguły mała skala przedsięwzięcia, wykorzystanie osobliwości regionu, tradycji regionalnych, kontakt z krajobrazem i naturą, dbałość o zachowanie specyficznych cech danego regionu.

Należy uwzględnić, że w zależności od regionu geograficznego oraz od roli jaką odgrywają społeczność wiejska i rolnictwo w danym kraju czy regionie, zmienia się zakres pojęcia agroturystyki, a także zmieniają się relacje między pojęciami agroturystyka, a turystyka wiejska.

\section{Turystyka wiejska i agroturystyka w Europie i w Polsce}

Turystyka jest ważną częścią rynku wewnętrznego Unii Europejskiej, a do głównych wyzwań stojących przed turystyką europejską ${ }^{3}$ należą: podnoszenie swojej konkurencyjności przemysłu turystycznego oraz zrównoważenie w zakresie miejsc - celów podróży (destynacji).

Turystyka wiejska, w tym szczególnie agroturystyka od wielu lat rozwija się $\mathrm{i}$ jest ważną pozycją w zakresie popytu na usługi wypoczynkowe - mając poparcie i wsparcie finansowe władz państwowych i samorządów lokalnych, gdyż pojawienie się sieci gospodarstw agroturystycznych pociąga za sobą roz-

${ }^{3}$ Kierunki prowadzony ch na szczeblu UE działań w turystyce zostały określone w Komunikacie Komisji z marca 2006 r. zatytułowanym "Odnowiona polityka turystyczna UE: Ku silniejszemu partnerstwu na rzecz turystyki europejskiej”. 
wój całego regionu. Znaczącym atutem agroturystyki stała się ekologiczna żywność, regionalne potrawy, a także specyficzne atrakcje, np.: dla dzieci miejskich spotkania ze zwierzętami, wypicie szklanki mleka prosto od krowy, jazda konna lub udział w pracach rolnika. Uznaniem europejskich turystów cieszą się też pikniki organizowane na farmie i restauracje wiejskie z regionalnymi potrawami.

Zainteresowanie agroturystyką w Polsce jest znaczące, zwłaszcza ze strony rolników i instytucji związanych ze wsią, a w wielu programach lokalnych, jak również rządowych ${ }^{4}$ - wskazuje się na potrzeby rozwoju agroturystyki, jako źródła zwiększenia dochodu rolników i zmniejszenie bezrobocia na wsi.

W aspekcie marketingowym wyróżnia się dwie grupy czynników, które skłaniają turystów do odwiedzania danego rejonu: czynniki zewnętrzne: atrakcyjność krajobrazowa danego rejonu i jego nasycenie obiektami zabytkowymi oraz czynniki wewnętrzne: standard bazy turystycznej, jakość usług agroturystycznych, życzliwość gospodarzy, nieskażone środowisko naturalne oraz mające duże znaczenie dla turystów walory kulturowe regionu: interesujące obiekty, tradycyjne rzemiosło, gwara, dania regionalne, imprezy folklorystyczne.

Głównym uwarunkowaniem atrakcyjności regionu jest dostosowanie jego infrastruktury do standardów europejskich, co zależy od samorządów lokalnych i nakładów finansowych ${ }^{5}$.

Z badań i danych GUS ${ }^{6}$ wynika, że liczba udzielonych noclegów w kwaterach agroturystycznych w 2016r. w stosunku do 2015r., wzrosła, o ok. 14\%.

\footnotetext{
${ }^{4}$ Ministerstwo Sportu i Turystyki, Strategia rozwoju turystyki na lata 2008-2014 (projekt), Warszawa, luty 2008. Proponowane w Strategii rozwoju turystyki na lata 2008-2014. kierunki rozwoju sprzyjają budowaniu silnych podstaw gospodarki turystycznej. Strategia określa zrównoważony rozwój sektora turystycznego w Polsce oraz wskazuje działania, w których realizację powinny być zaangażowane podmioty działające na rzecz rozwoju turystyki tzn. jednostki samorządu tery torialnego, organizacje pozarządowe, przedsiębiorcy, organizacje branżowe, środowisko naukowe i inni.

${ }^{5}$ A.P. Wiatrak, ,,Regionalne aspekty agroturystyki", Centrum Doradztwa i Edukacji, Kraków 1995, s.10-11.

${ }^{6}$ GUS Warszawa, 29.09.2016 r. Notatka informacyjna, Baza noclegowa według stanu w dniu 31 lipca 2016 r. i jej wykorzystanie w I półroczu 2016 r. W pierwszym półroczu 2016 r. w pokojach gościnnych i kwaterach agroturysty cznych posiadających 10 lub więcej miejsc noclegowych obiektach udzielono 890,6 tys. noclegów, z czego 717,6 tys. w pokojach gościnnych i 173,0 tys. w kwaterach agrotury sty cznych (w 2015 r. odpowiednio 772,6 tys., 620,4 tys. i 152,3 tys.). Turystom krajowym udzielono 826,9 tys. noclegów, a zagranicznym 63,8 tys. (w $2015 \mathrm{r}$. odpowiednio 717,4 tys. i 55,3 tys.). W porównaniu do analogicznego okresu w roku 2015 zaobserwowano wzrost liczby korzystających z tego rodzaju obiektów (o 17,1\%) oraz liczby udzielonych noclegów (o 15,3\%). Stopień wykorzystania miejsc noclegowych, w I półroczu 2016 r. dla pokoi gościnnych wyniósł $17,9 \%$, a dla kwater agrotury stycznych $10,2 \%$ (w 2015 r. odpowiednio $16,7 \%$ i $9,1 \%)$.
} 
Rozwój i efektywność działalności turystyki wiejskiej i agroturystyki jest uzależniona od współpracy społecznych i samorządowych podmiotów turystyki wiejskiej, a także od trafnego wyboru określonej formy specjalizacji w działalności turystycznej, jakości usług ${ }^{7}$.

\section{Tendencje i kierunki rozwoju w agroturystyce}

Doświadczenia krajów UE, polegające na wspieraniu wielorakich form działalności gospodarczej - w tym również agroturystyki, potwierdzają możliwości zwiększania zatrudnienia i dochodów ludności wiejskiej, poprzez aktywny udział lokalnej społeczności w opracowaniu i realizacji programów wielokierunkowego rozwoju gmin wiejskich oraz umiejętnego kojarzenia inicjatyw i środków własnych z formami pomocy z zewnątrz.

W Polsce, na wzór stowarzyszeń zachodnioeuropejskich, zaczyna kształtować się przekonanie do sprawnej organizacji koordynującej i inspirującej lokalne działania agroturystyczne oraz prowadzenia efektywnej polityki marketingowej. Są organizowane z inicjatywy władz rządowych i samorządowych Ogólnopolskie Sympozja Agroturystyczne, które stają się forum dyskusji w zakresie kierunków rozwoju agroturystyki ${ }^{9}$ i określają kierunki rozwoju i trendy polskiej agroturystyki oraz potrzeby aktywności społecznej zarówno mieszkańców jak

${ }^{7}$ Zawiązują się lokalne stowarzyszenia osób świadczący ch usługi turystyczne w celu prowadzenia wspólnej promocji (np. Gospodarstwo Gościnne"). Obecnie działa ok. 60 stowarzyszeń, ale w wielu gminach brak tego typu działań zespołowych.

${ }^{8} \mathrm{~Np}$. Federacja Turystyki Wiejskiej „Gospodarstwa Gościnne”, która ma własne strony ofert internetowych,. Udostępnione także są: at las agrotury sty czny Polski, liczne publikacje folderów, poradniki dla rozpoczynających działalność agroturystyczną. Realizowany jest aktywny udział w międzynarodowy ch targach i wy stawach tury sty czny ch, itp.

${ }^{9} \mathrm{~Np}$. Sympozjum Agroturystyczne już w 2003 r. za priorytety w rozwoju agroturystyki uznało m. innymi, że: warunkiem rozwoju turystyki wiejskiej jest: współdziałanie stowarzyszeń turystyki wiejskiej z samorządami na szczeblu lokalnym, powinny być tworzone produkty dla klientów o specjalistycznych zainteresowaniach, w promocji turystyki wiejskiej należy przyjąć zasadę koncentracji na najważniejszych rynkach, - rozwój usług agroturystycznych wymaga systematycznego podnoszenia wiedzy, umiejętności oraz kształtowania pozytywnych postaw i kreatywności usługodawców, ważnym dla turystyki wiejskiej w Polsce, jest spełnienie unijnych wymagań w zakresie produkcji żywności i obrotu żywnością. Natomiast celem XVI Ogólnopolskiego Sympozjum Agroturystycznego (15-17 września 2015r.) była wymiana poglądów, osiągnięć i doświadczeń w zakresie tematu „Innowacyjność w turystyce wiejskiej a nowe możliwości zatrudnienia na obszarach wiejskich", obejmującego m.in. zagadnienia: potencjału innowacyjnego produktów tury styki wiejskiej, aktywizacji rynku pracy na obszarach wiejskich poprzez turystykę, innowacyjne zarządzanie rozwojem turystyki wiejskiej, instytucjonalne wspieranie i upowszechnianie rozwiązań innowacyjnych w tury styce, innowacje na wiejskim rynku tury stycznym. 
i organów samorządowych w tworzeniu wizji kompleksowego zagospodarowania lokalnego potencjału, poprzez wykorzystanie istniejących zasobów krajoznawczych, kulturowych i ludzkich oraz inicjowania procesów różnicowania rozwoju wielofunkcyjności obszarów wiejskich i rozwiązań prowadzących do przezwyciężenia bierności i ożywienia przedsiębiorczości na wsi.

\section{Synergia agroturystyki w dywersyfikacji obszarów wiejskich}

Program dywersyfikacji ekonomicznej i poprawy jakości życia na wsi był jednym z zasadniczych elementów polityki UE i Strategii Rozwoju Kraju 20072015 w zakresie rozwoju obszarów wiejskich. Nowa polityka rozwoju obszarów wiejskich kładzie większy niż dotychczas nacisk m.in. na pozaprodukcyjne funkcje i zrównoważony rozwój obszarów wiejskich. Przyjęta strategia i jej priorytety, obejmuje cele:

- podjęcie lub rozwój dodatkowej działalności, wykorzystującej istniejące zasoby,

- umożliwienie do rozwoju wielofunkcyjnych i trwałych ekonomicznie gospodarstw,

- sprzyjanie tworzeniu alternatywnych źródeł dochodów,

- promowanie wizerunku wsi i rolnictwa w społeczeństwie,

- sprzyjanie zachowania walorów przyrodniczych obszarów wiejskich,

- ułatwienie dostępu rolnikom oraz pozostałym mieszkańcom wsi do usług,

- przyczynianie się do zwiększenia produkcji rolnej.

Różnicowanie działalności gospodarczej na obszarach wiejskich, stanowi szansę dla mieszkańców wsi, a oferowanie oprócz podstawowych składników produktu turystycznego jakimi są zakwaterowanie i wyżywienie, również innych usług rodzi dalsze możliwości aktywizacji mieszkańców oraz zatrudnienia i dodatkowych dochodów.

Podstawowe składniki oferty agroturystycznej przedstawiono w tabeli 1.

Agroturystyka będąc istotnym czynnikiem rozwoju gospodarczego terenów wiejskich pobudza również rozwój społeczny na wsi, w tym umacnia poczucie własnej wartości mieszkańców, wzbudza lokalny patriotyzm, zwiększa dbałość wioskowej społeczności o wygląd wsi, wzmaga zainteresowanie i troskę o lokalną architekturę, pamiątki kultury materialnej, tradycyjne rzemiosło, rękodzielnictwo, sztukę kulinarną, itp. 
Składniki ofert turystyki wiejskiej i agroturystyki

\begin{tabular}{|c|c|c|c|c|}
\hline \multicolumn{5}{|c|}{ Składniki oferty turystyki wiejskiej i agrotury styki } \\
\hline zakwaterowanie & $\begin{array}{c}\text { atrakcje } \\
\text { środowiska }\end{array}$ & $\begin{array}{c}\text { dostępne } \\
\text { urządzenia }\end{array}$ & $\begin{array}{l}\text { spędzanie } \\
\text { czasu }\end{array}$ & $\begin{array}{c}\text { możliwe } \\
\text { usługi }\end{array}$ \\
\hline $\begin{array}{l}\text { Dom w gospodarstwie } \\
\text { rolnym } \\
\text { Noclegi i samodzielne } \\
\text { wyży wienie } \\
\text { Przyczepy kempingowe } \\
\text { Kempingi } \\
\text { Namioty/szałasy } \\
\text { Schroniska }\end{array}$ & \begin{tabular}{|l} 
Góry \\
Jeziora \\
Rzeki \\
Morze \\
Bagna \\
Krajobraz \\
Świeże \\
powietrze \\
Las
\end{tabular} & $\begin{array}{l}\text { Szlaki tury- } \\
\text { styczne: } \\
\text { konne, rowe- } \\
\text { rowe, } \\
\text { spacerowe, } \\
\text { Kluby } \\
\text { Obiekty: } \\
\text { sportowe } \\
\text { kulturalne } \\
\text { Oświatowe } \\
\text { Rzemiosło itp. }\end{array}$ & $\begin{array}{l}\text { Praca w gospo- } \\
\text { darstwie } \\
\text { Jeździectwo } \\
\text { Sporty wodne } \\
\text { Udział w impre- } \\
\text { zach kulturalnych } \\
\text { Hobby } \\
\text { Uczenie się: } \\
\text { języków, itp. }\end{array}$ & $\begin{array}{l}\text { Opieka nad dziećmi } \\
\text { Pralnia, poczta } \\
\text { Restauracja } \\
\text { Sklep/bank } \\
\text { Agencja turystycz- } \\
\text { na } \\
\text { Komunikacja } \\
\text { Wypożyczalnia } \\
\text { Schronisko dla } \\
\text { psów itp. }\end{array}$ \\
\hline
\end{tabular}

Źródło: K. Borkowski, Agroturystyka. Materiały szkoleniowe, MG, Departament Turystyki, 2002 s. 87.

Obecność turystów w obrębie gospodarstwa jak i na terenie wsi wzmaga działania na rzecz czystości i estetyki, podnosząc w perspektywie jakość życia samych mieszkańców ${ }^{10}$ oraz zwiększa popyt na różnego typu dobra i usługi o charakterze nieturystycznym - stymulując przez to rozwój wiejskiej infrastruktury.

Powstające obiekty handlowe i gastronomiczne, komunikacja, usługi bankowe i pocztowe, apteki i ośrodki zdrowia, stacje benzynowe i obsługi samochodów służyć będą nie tylko turystom lecz, także stałym mieszkańcom, przyczyniając się do poprawy ich obsługi i zapewniając równocześnie większą rentowność całej sieci usługowej, co oznacza kolejne miejsca pracy i źródła zarobkowania.

W konkluzji należy uznać, że wzajemne powiązanie różnych przedsięwzięć gospodarczych, społecznych, infrastrukturalnych, organizacyjnych a nawet marketingowych, w ramach lokalnych programów samorządowych, oraz preferowanie i rozwoju agroturystyki - może być skutecznym czynnikiem w przezwyciężaniu lokalnych problemów.

${ }^{10}$, Regionalne aspekty agroturystyki", Centrum Doradztwai Edukacji, Kraków1995. 


\section{Rola władz lokalnych i instrumenty wsparcia w rozwoju lokalnym}

Wspieranie przedsiębiorczości na wsi, często uwarunkowane czynnikami zewnętrznymi o charakterze systemowym, stało się ważnym elementem działalności samorządowej decydującej o rozwoju funkcji pozarolniczych i przemian na obszarach wiejskich oraz o poprawie statusu ekonomicznego rodzin wiejskich i rolniczych. Sprzyjanie rozwojowi przedsiębiorczości wiejskiej i tworzenie nowych podmiotów gospodarczych, w efekcie przyczynia się do samowystarczalności gminy, pod względem dostępu do różnych produktów i usług, poprawia wizerunek gminy na zewnątrz (promocja gminy) oraz przeciwdziała wyludnianiu się obszarów wiejskich, a także przynosi korzyści finansowe nie tylko osobom bezpośrednio $\mathrm{w}$ nią zaangażowanym, ale również samej gminie $\mathrm{w}$ postaci wpływów z opłat i podatków stanowiących część dochodów budżetu samorządu $^{11}$. Znaczącą rolę $\mathrm{w}$ rozwoju lokalnym mają urzędy gmin, z ukierunkowaną działalnością samorządów na aktywizację społeczności lokalnej, pobudzanie inicjatywy gospodarczej wśród mieszkańców gminy i tworzenie warunków do podejmowania działalności gospodarczej oraz eliminację barier rozwoju przedsiębiorczości ${ }^{12}$ i udzielanie wsparcia osobom, które tę inicjatywę wykazują.

W zakresie kompetencji i dyspozycji samorządów jest szerokie spektrum instrumentów ${ }^{13}$ organizacyjnych i prawno-finansowych, które stosowane kompleksowo na podstawie planu zagospodarowania przestrzennego i planu rozwoju gospodarczego - tworzą sprzyjające warunki do rozwoju lokalnej przedsiębiorczości, w tym również agroturystyki. Wspieranie lokalnej przedsiębiorczości na terenie gminy $^{14}, \mathrm{w}$ tym także podmiotów $\mathrm{w}$ obszarach agroturystyki, jest realizowane m.in. poprzez: współdziałanie $\mathrm{z}$ przedsiębiorcami $\mathrm{w}$ uzyskiwaniu unijnych środków pomocowych, tworzenie funduszy doręczeniowo-pożyczkowych, punktów informacyjnych, organizację szkoleń, obniżanie podatków i opłat lokalnych, two-

${ }^{11}$ G. Czapiewska, Rola instytucji i władz lokalnych w rozwoju przedsiębiorczości wiejskiej, Wydział Zarządzania i Administracji Uniwersytetu Humanistyczno - Przyrodniczego Jana Kochanowskiego w Kielcach, Studia i Materiały. Miscellanea Oeconomicae, Rok 14, Nr 1/2010, Kielce 2010.

${ }^{12}$ A. Rosner, Rola samorządu lokalnego w rozwoju przedsiębiorczości, w: Przedsiębiorczość wiejska w Polsce i krajach Unii Europejskiej, M. Kłodziński, B. Fedyszak-Radziejowska (red.), IRWiR PAN, Warszawa 2002.

${ }^{13}$ Najważniejszymi instrumentami wspierania przedsiębiorczości są: budżet gminy, ujmujący całokształt wsparcia przedsiębiorczości, w tym także obniżanie podatków i opłat lokalnych, rozwój infrastruktury technicznej, w tym głównie drogowej oraz sprawna sieć kanalizacyjno - wodociągowa oraz tereny pod inwestycje, oraz zaktualizowane plany zagospodarowania przestrzennego gminy.

${ }^{14}$ A. Kożuch, Rola samorzadu terytorialnego we wspieraniurozwoju lokalnego, w: Monografie i Studia Insty tutu Spraw Publicznych Uniwersy tetu Jagiellońskiego, Kraków 2011, s.17 i dalsze. 
rzenie lokalnej witryny internetowej dla potrzeb marketingu oraz promocja wszelkich walorów i możliwości rozwojowych regionu.

Europejskie instrumentarium wsparcia rozwoju lokalnego ze środków UE na lata $2007-2013^{15}$ były ukierunkowane głównie dla lokalnych samorządów, budżetowych jednostek samorządu terytorialnego oraz dla instytucji publicznych i organizacji pozarządowych. Bezpośrednim instrumentem wsparcia unijnego dla rozwoju wsi stał się Europejski Fundusz Rolny Rozwoju Obszarów Wiejskich (EFRROW), który na poziomie lokalnym był skierowany na wspieranie regionów krajów członkowskich o strukturze typowo rolniczej, dla finansowania projektów dotyczących zrównoważonego rozwoju - w tym także: rozwój przedsiębiorczości, ułatwienie dostępu do usług, rozwój agroturystyki, działania na rzecz rozwoju infrastruktury obszarów wiejskich.

Dotychczasowa absorpcja wsparcia unijnego zaktywizowała społeczności lokalne, zainicjowała procesy rozwoje i innowacyjne oraz wykorzystanie lokalnego potencjału gospodarczego, społecznego, turystycznego, kulturowego, a władze lokalne wykazały się umiejętnością skutecznego aplikowania i zarządzania środkami finansowymi i generowania wkładu własnego ${ }^{16}$.

Aktualnie celami bezpośrednimi rozwoju lokalnego kierowanego przez społeczność (wg propozycji KE na lata 2014-2020) są ${ }^{17}$ :

- zintegrowane podejście oddolne w okolicznościach potrzeby zmian strukturalnych;

- budowanie społeczności i stymulowanie innowacyjności, przedsiębiorczości i możliwości zmian poprzez zachęcanie do rozwoju i odkrywania niewykorzystanego potencjału;

- promowanie poczucie własności społeczności poprzez zwiększanie uczestnictwa oraz budowanie zaangażowania, dla zwiększenia efektywności regulacji unijnych;

\footnotetext{
${ }^{15}$ Fundusze strukturalne:Europejski Fundusz Społeczny (EFS) i Europejski Fundusz Rozwoju Regionalnego (EFRR), któresą realizowane poprzez tzw. Programy Operacyjne (PO), a odpowiednie priorytety i działania Programów Operacyjny ch doty czą rozwoju lokalnego, w tym m. innymi: PO Rozwój Obszarów Wiejskich (w tym: oś priorytetowa 3: Jakość życia na obszarach wiejskich i różnicowanie gospodarki wiejskiej). Uzupełniająco dla p oszczególnych województw są realizowane Regionalne Programy Operacyjne (RPO), ze specyficznymi dla danego regionu priorytetami, jak np.; poprawaśrodowiska nat uralnego, zachowanie różnorodności biologicznej i ochrona przyrody, realizacja zrównoważonego rozwoju, wy korzystanie i promocja potencjału turystycznego, zachowanie i ochrona dziedzictwa kulturowego, itp.

${ }^{16}$ J. Ruszkowski, Europejskie wsparcie rozwoju lokalnego, Zeszyty Naukowe 1/2008, wyd. Wyższa Szkoła Administracji Publicznej w Szczecinie, Szczecin 2008, s. 93-105.

${ }^{17}$ Rozwój lokalnykierowany przez społeczność, UE LSR community_pl.pdf, mat. Komisji Europejskiej, ec.europa.eu .
} 
- wspomaganie zarządzania wielopoziomowego poprzez zapewnienie społecznościom lokalnym udziału w kształtowaniu realizacji celów UE we wszystkich obszarach.

Wspierane programów rozwoju obszarów wiejskich unijnymi stanowi instrument polityki interwencyjnej państwa również wobec sektora turystyki wiejskiej, który daje szanse wielofunkcyjnego rozwoju obszarów wiejskich, a tym samym jest on istotnym instrumentem wspierającym proces modernizacji polskiej wsi ${ }^{18}$.

Synergia agroturystyki ściśle związana $\mathrm{z}$ wieloma instrumentami różnicowania gospodarki obszarów wiejskich i działań dotyczących poprawy jakości życia, staje się głównym czynnikiem rozwojowym oraz komplementarnym źródłem dochodów i miejsc pracy. Oceniając czynniki rozwoju agroturystyki należy uwzględniać jej rozwój, jako turystyki zrównoważonej, czyli takiej, której infrastruktura i formy odzwierciedlają troskę o stan obecny i przyszłość środowiska naturalnego, a jednocześnie o rozwój ekonomiczny lokalnej społeczności i zachowanie kulturowej tożsamości.

Rozwój zrównoważony (zintegrowany) powinien ujawniać się w integracji działających lokalnie podmiotów, środków finansowych oraz działań wywołujących efekty synergiczne. Trwały, zrównoważony rozwój jest bowiem możliwy tylko w zintegrowanych i racjonalnie zorganizowanym zarządzaniu gospodarką, wraz z zastosowaniem nowoczesnych systemów informatycznych ${ }^{19}$.

\section{Rola turystyki wiejskiej w rozwoju lokalnym}

Wzrost zainteresowania mieszkańców miast agroturystyką, jako formą aktywnego wypoczynku w naturalnym środowisku było nie tylko szansą dla poszczególnych gospodarstw rolnych, ale także dla całej gminy. Dobrze o tym wiedzą mieszkańcy wsi i dlatego tworzą odpowiedni klimat do rozwoju tej formy gospodarowania. Motywacje do podjęcia działalności agroturystycznej w badanych gospodarstwach zestawiono w tabeli 2 .

Rolnicy zdają sobie sprawę, że agroturystyka może przysporzyć im dodatkowego dochodu i być jedną z dróg do osiągnięcia niezależności finansowej gospodar-

${ }^{18}$ M. Wigier, K. Chmurzyńska, Interwencjonizm $w$ agrobiznesie na przykładzie PROW 2007-2013, teoria i praktyka, Zeszyty Naukowe SGGW w Warszawie, Ekonomika i Organizacja Gospodarki Żywnościowej, nr 90 , wyd. SGGW Warszawa, 2011, s.32.

${ }^{19}$ M. Słodowa-Hełpa, Warunki i czynniki rozwoju turystyki w gminie, publ., Katedra Historii Gospodarczej Akademii Ekonomicznej, Poznań. 
stwa. Agroturystyka stwarza zupełnie nowe możliwości użytkowania przestrzeni wiejskiej, zabudowań rolniczych, lokalnej infrastruktury, zaś uzyskiwane przez mieszkańców dodatkowe dochody stanowią zalążek aktywizacji gospodarczej gminy. Powodzenie jednak z tej działalności może przynieść korzyści tylko wtedy, gdy zarówno dom, pokoje, jak i cała zagroda spełnia odpowiednie warunki.

Tabela 2

Motywacje dla podjęcia działalności agroturystycznej

\begin{tabular}{|l|c|c|}
\hline \multicolumn{1}{|c|}{ Wyszczególnienie } & $\begin{array}{c}\text { Liczba } \\
\text { gospodarstw }\end{array}$ & $\begin{array}{c}\text { Ogół badanych } \\
\text { gospodarstw (\%) }\end{array}$ \\
\hline Uzyskanie dodatkowych dochodów & 9 & 31,0 \\
\hline Wykorzystanie bazy noclegowej & 6 & 20,7 \\
\hline Atrakcyjne położenie gospodarstwa & 7 & 24,1 \\
\hline Brak innej pracy & 5 & 17,2 \\
\hline $\begin{array}{l}\text { Sprzedaż nadwyżek produktów wytwarzanych } \\
\text { w gospodarstwach }\end{array}$ & 2 & 6.9 \\
\hline
\end{tabular}

Źródło: opracowanie na podstawie danych z Urzędu Gminy w Janowie.

Wkład agroturystyki w rozwój obszarów wiejskich trudno jest przecenić. Dotyczy głównie spraw zatrudnienia, wzrostu dochodów rolników, poprawy stanu infrastruktury społecznej i podniesienia ogólnego poziomu życia mieszkańców gminy ${ }^{20}$. Turystyka wiejska, w tym agroturystyka przyczynia się też do utworzenia dodatkowego rynku zbytu na produkty żywnościowe i różnego rodzaju usługi a także do rozwoju specyficznych form gospodarowania np. rolnictwa ekologicznego. Małe gospodarstwa słabo radzące sobie z konkurencją, znajdują dzięki turystyce dodatkowe źródła dochodów. Mała skala zabudowy i produkcji, silne tradycje, lokalne zwyczaje i potrawy, warzywa z własnego ekologicznego ogrodu - to wszystko osiągalne jest tylko w drobnych gospodarstwach, które w przeciwnej sytuacji skazane by były na zagładę. Zjawisko to wzbogaca społeczność wiejską i w dużej mierze przyczynia się do ograniczenia odpływu ludności ze wsi do miasta, co z kolei likwiduje problem starzenia się wsi i braku rąk do pracy ${ }^{21}$.

Obserwuje się coraz więcej właścicieli gospodarstw zainteresowanych działalnością agroturystyczną. Wiąże się to zarówno z sytuacją ekonomiczną gminy, jak i indywidualnych gospodarstw, które upatrują z tej działalności więk-

${ }^{20}$ F. Morski, Rozwój turystyki i rekreacji w gminach województwa ślaskiego, Śląski Związek Gmin i Powiatów, 1999.

${ }^{21}$ A. Gannon, E. Kmita, Agroturyzm a rozwój wsi. Centrum Doradztwa i Edukacji w Rolnictwie, Kraków 1993. 
sze dochody i zyski dla poprawienia swojej sytuacji materialnej. Rolnicy zdają sobie sprawę, że agroturystyka może przysporzyć im dodatkowego dochodu i być jedną z dróg do osiągnięcia niezależności finansowej gospodarstwa. Powodzenie jednak z tej działalności może przynieść korzyści tylko wtedy, gdy zarówno dom, pokoje, jak i cała zagroda spełnia odpowiednie warunki, w tym również infrastruktura wsi i całej gminy, która wpływa na konkurencyjność wyboru przez turystów miejsca wypoczynku. Turysta musi czuć, iż to on jest najważniejszy dla gospodarza, u którego wynajmuje pokój. Dlatego przystosowanie pomieszczeń do podjęcia gości wymaga wiele wysiłku, pomysłowości i nakładów finansowych ze strony rolnika.

Organizowane na terenie gminy plenerowe imprezy przyczyniają się do wzrostu popularności danego regionu i przyciągają turystów uatrakcyjniając im pobyt, a także stwarzają tendencję imigracyjną, gdyż wiele osób wykupuje działki chcąc się osiedlić w atrakcyjnym terenie. Gwarantuje to dobre warunki dla regularnej wymiany substancji mieszkaniowej i rozwoju budownictwa, które jak wiadomo są funkcją wzrostu zaludnienia i dochodów ludności. Agroturystyka jest bez wątpienia bodźcem ekonomicznym i czynnikiem rozwoju gminy.

Działalność gospodarcza w sektorze turystycznym oznacza wielkie zmiany dla mieszkańców wsi, którzy do tej pory prowadzili gospodarstwo rolne. Oznacza prowadzenie całkiem innego rodzaju działalności gospodarczej, jak też zmiany socjalne na wsi. ${ }^{22}$ Wydaje się, że mentalność ludzi, która początkowo była czynnikiem hamującym została w gminie Janów przełamana. Strach przed nowym i nieznanym ustąpił chęci poznania i skorzystania $z$ dodatkowych dochodów. Przełamano też barierę „obcej osoby" w gospodarstwie, a turystę zaczęto traktować jako gości pożądanych. Na taki stan rzeczy bez wątpienia wpłynęły szkolenia i długi proces adaptacyjny oraz bezpośrednia obserwacja turystów w innych gospodarstwach.

Aktywizacja społeczno-ekonomiczna gminy poprzez rozwój turystyki wiejskiej w regionie ma duży wpływ na proces restrukturyzacji rolnictwa. Spadek znaczenia rolnictwa, jako dziedziny zapewniającej miejsca pracy oraz źródło ich dochodów, spowodował, że rozwój ekonomiczny wsi i poprawa warunków życia na wsi nie muszą być dokonywane wyłącznie przez rozwój produkcji rolnej. Wielofunkcyjny rozwój wsi związany z różnicowaniem zawodów i zajęć na wsi, przy

${ }^{22}$ A. Wiatrak, Regionalne aspekty agroturystyki, Centrum Doradztwa i Edukacji w Rolnictwie Oddz. w Krakowie 1995. 
przechodzeniu rolników od gospodarowania do drobnej przedsiębiorczości: turystyki, gastronomii, rzemiosła i usług, sprzyja wykorzystaniu zasobów pracy oraz podaży produktów regionalnych ${ }^{23}$. Szukanie nowych rozwiązań stanowi zadanie dla rolników i wszystkich mieszkańców wsi. Rozwiązania te powinny prowadzić do alternatywnego wykorzystania zasobów gospodarstwa rolnego i regionu.

Potencjalne źródło dochodu i miejsc pracy dla mieszkańców wsi może stanowić agroturystyka, która staje się ważnym elementem w ożywieniu gospodarki wiejskiej. Decydują o tym unikatowe wartości środowiska naturalnego i jego walory przyrodnicze oraz krajobrazowe, które stwarzają warunki dla rozwoju wypoczynku, jak również dają możliwość różnokierunkowego rozwoju działalności pozarolniczej. Istnieje swoiste sprzężenie zwrotne, w którym turystyka jest czynnikiem napędzającym koniunkturę gospodarczą i przemiany systemowe, ale czynniki zewnętrzne mają wpływ na sukces ekonomiczny turystyki ${ }^{24}$. Turystyka to dla gospodarki lokalnej ważne źródło dochodu i czynnik rozwoju.

\section{Podsumowanie}

Przedsiębiorczość pozarolnicza kompleksu turystyki na obszarach wiejskich stanowi podstawę ożywienia gospodarczego i jest czynnikiem stymulującym tworzenie nowych miejsc pracy. Stanowi podstawę rozwoju społeczno-gospodarczego, szczególnie dla regionów o niskim poziomie zurbanizowania i dużego rozdrobnienia rolnictwa. Dywersyfikacja źródeł zarobkowania mieszkańców wsi, jest ważnym determinantem realizacji polityki rozwoju zrównoważonego.

Rozwój sektora turystyki na obszarach wiejskich w znacznym stopniu uwarunkowany jest sprawnością funkcjonowania instytucji wiejskich, w tym głównie lokalnych władz. Samorząd mając do dyspozycji szerokie spektrum różnych form wspierania przedsiębiorczości może kreować rozwój turystyki wiejskiej, poprzez inspirację i motywację agrobiznesu z potrzebami miejscowej ludności oraz istniejącym potencjałem danego regionu. Aktualnie wsparcie samorządów ukierunkowane jest głównie na działania posiadające wsparcie z środków unijnych, np. w zakresie infrastruktury, szkoleń, doradztwa. Natomiast działania, które wynikają z lokalnych inicjatyw i wymagających zaangażowania własnych środków gminy, są realizowane relatywnie rzadziej, co wskazuje na celowość

${ }^{23}$ T. Wirkiewicz, Aktywizacja spoleczno-ekonomiczna regionu poprzez rozwój turystyki wiejskiej. Regionalne Centrum Doradztwa w Starym, Polu 2000.

${ }^{24}$ A. Lipska, Lokalna polityka turystyczna i marketing. Insty tut Turystyki w Krakowie 1995. 
pogłębiania współpracy lokalnych władz z organizacjami i stowarzyszeniami pracującymi na rzecz rozwoju przedsiębiorczości wiejskiej. Istotnym elementem powodzenia $\mathrm{w}$ realizacji programów rozwojowych jest skuteczne wykorzystanie unijnych instrumentów wsparcia dla pobudzania aktywności gospodarczej społeczności lokalnej, m.in. przez prowadzenie polityki informacyjnej, która daje mieszkańcom poczucie, że współuczestniczą w decydowaniu o sprawach gminy.

Podjęcie działalności gospodarczej w sektorze turystycznym oznacza ważne zmiany socjalne na wsi i wpływa na proces restrukturyzacji rolnictwa. Zmienia mentalność mieszkańców, którzy w turystyce zaczynają upatrywać możliwości dodatkowych dochodów.

Aktywna polityka lokalna i regionalna wspierania rozwoju agroturystyki jest uzależniona od dysponowanych środków finansowych i aktualnie głównie ukierunkowana jest na działania posiadające wsparcie z środków unijnych, np. w zakresie infrastruktury, szkoleń, doradztwa. Natomiast działania, które wynikają z lokalnych inicjatyw i wymagają zaangażowania własnych środków gminy, są realizowane relatywnie rzadziej, co wskazuje na celowość pogłębiania współpracy lokalnych władz z organizacjami i stowarzyszeniami pracującymi na rzecz rozwoju przedsiębiorczości wiejskiej, aby programy rozwoju turystyki wiejskiej uwzględniały specyfikę regionu.

\section{Bibliografia}

Czapiewska G., Rola instytucji i wladz lokalnych w rozwoju przedsiębiorczości wiejsk iej, Uniwersytetu Humanistyczno-Przyrodniczego w Kielcach, Studia i Materiały. Miscellanea Oeconomicae, rok $14 \mathrm{nr}$ 1/2010, Kielce 2010.

Ministerstwo Gospodarki, Strategia rozwoju turystyki w latach 2001-2006, Warszawa 2001.

GUS Notatka informacyjna, Baza noclegowa, Warszawa 29.09.2016.

Knecht D., Agroturystyka w agrobiznesie, wyd. C,H, Beck, Warszawa 2009.

Kożuch A., Rola samorzadu terytorialnego we wspieraniu rozwoju lokalnego, w: Monografie i Studia Instytutu Spraw Publicznych UJ, Kraków 2011.

Morski F., Rozwój turystyki i rekreacji w gminach województwa śląskiego, Śląski Związek Gmin i Powiatów,1999.

Rosner A., Rola samorzadu lokalnego w rozwoju przedsiębiorczości, w: Przedsiębiorczość wiejska w Polsce i krajach Unii Europejskiej, M. Kłodziński, B. FedyszakRadziejowska (red.), IRWiR PAN, Warszawa 2002.

Ruszkowski J., Europejskie wsparcie rozwoju lokalnego, Zeszyty Naukowe 1/2008, wydawnictwo Wyższa Szkoła Administracji Publicznej w Szczecinie, Szczecin 2008. 
Sarzyńska A., Przedsiębiorczość wiejska w Polsce i krajach Unii Europejskiej, EIC Warszawa, biuletyn 01/03, oprac. wg artykułu M. Kłodzińskiego, PAN, Warszawa 2002.

Słodowa-Hełpa M., Warunki i czynniki rozwoju turystyki w gminie, Katedra Historii Gospodarczej Akademii Ekonomicznej, Poznań.

Wiatrak A.P., Baza agroturystyczna w Polsce $i$ uwarunkowania jej rozwoju, Zeszyty Naukowe Akademii Rolniczej im. H. Kołłątaja w Krakowie nr 402, 2003

Wigier M., Chmurzyńska K., Interwencjonizm w agrobiznesie na przykładzie PROW 2007-2013, teoria i praktyka, Zeszyty Naukowe SGGW w Warszawie, Ekonomika i Organizacja Gospodarki Żywnościowej, Wydawnictwo SGGW, nr 90 , Warszaw 2011.

Wirkiewicz T. Aktywizacja społeczno-ekonomiczna regionu poprzez rozwój turystyki wiejskiej i promocje produktów regionalnych jako czynnik wplywajacy na wielofunkcyjny rozwój obszarów wiejskich", Regionalne Centrum Doradztwa, Stare Pole 2000.

ec.europa.eu, Rozwój lokalny kierowany przez społeczność, UE LSR community_pl.pdf www.janów.pl.

www.polskawliczbach.p1/gmina_Janow_slaskie\#ixzz4MuOoP28s.

www.ppr.pl, L. Strzelbicki., Uwarunkowania rozwoju agroturystyki i ustug towarzyszacych na obszarach wiejskich, (dostęp 19.05.2004).

\section{Aspect of agrotourism in local development}

\section{Summary}

The article describes the general tendencies and trends in complexity of rural tourism and agribusiness in the European Union and in Poland as well as the importance of rural tourism and agrotourism in the realization of social, economic and institutional objectives of local development. Existing EU and national terms of support of the local development were presented. Specific aspects of diversification of rural and local development were pointed. The role and the forms of participation of local authorities in the process of encouraging entrepreneurship and supporting socioeconomic development of rural areas were presented. 